\title{
Combined Bone Marrow Stem Cell Therapy and Coronary Artery Bypass Grafting for Ischemic Heart Diseases
}

\author{
Kamal S Ayyat ${ }^{1,2,3 *}$, Ahmed M Deebis ${ }^{1}$, Nader A Elboray ${ }^{1}$, Khaled H Abdelbary ${ }^{1}$ and Kenneth R McCurry ${ }^{2,3}$ \\ ${ }^{1}$ Department of Cardiothoracic Surgery, Zagazig University, Egypt \\ ${ }^{2}$ Department of Pathobiology, Lerner Research Institute, Cleveland Clinic Foundation, USA \\ ${ }^{3}$ Department of Thoracic and Cardiovascular Surgery, Cleveland Clinic, USA
}

Submission: February 10, 2017; Published: March 27, 2017

*Corresponding author: Kamal S Ayyat, 9500 Euclid Avenue, NB2-20 Lerner Research Institute, Cleveland, OH, USA 44195, USA,

Telephone: +14403191214; Email: dr_kamal_ayyat@yahoo.com

\begin{abstract}
Ischemic heart disease (IHD) is a major cause of mortality and morbidity worldwide. It caused 1 of every 6 deaths in the United States in 2008. Patients with serious IHD are usually presented with large areas of myocardial infarction affecting the cardiac functions and may even cause ischemic cardiomyopathy and heart failure. The efficacy of coronary artery bypass grafting (CABG) surgery alone for these patients is unclear. However, the field of myocardial regeneration utilizing novel bone marrow stem cell (BMSC) therapy may prove to play an important role in the future of IHD management. Promising results of preclinical and experimental studies have led to several clinical trials evaluating the feasibility, safety, and efficacy of combining CABG with BMSC therapy in treating patients with serious IHD. This systematic review discusses different methods of BMSCs delivery, their potential mechanism of action, and types.
\end{abstract}

Keywords: Stem cell therapy; Bone marrow stem cells; CABG; Ischemic heart disease; Myocardial infarction; Heart failure

Abbreviations: IHD: Ischemic Heart Disease; CABG: Coronary Artery Bypass Grafting; BMSC: Bone Marrow Stem Cell; MI: Myocardial Infarction; HF: Heart Failure; AHA: American Heart Association

"Truly in the body there is a morsel of flesh which, if it be sound, all the body is sound and which, if it be diseased, all of the body is diseased. Truly it is the heart." Prophet Muhammad

\section{Introduction}

Ischemic heart disease (IHD) is a major cause of mortality and morbidity worldwide. It caused 1 of every 6 deaths in the United States in 2008 [1]. It is also the major contributor to heart failure (HF) which has become a burgeoning disease. According to American Heart Association (AHA) projections, HF prevalence will increase by $46 \%$ from 2012 to 2030 [2]. Patients with serious IHD usually, have events such as myocardial infarction (MI) that can result in irreparable loss of viable cardiac mass dramatically affecting their cardiac functions. Despite the important advances achieved in revascularization procedures and medical therapy, many of these patients are left with significant disability [3]. Considering the unclear efficacy of coronary artery bypass grafting (CABG) surgery for these patients and the shortage of donor hearts, a rationale to develop a novel stem cell-based regenerative therapy was provided. Numerous studies using animal models have documented that bone marrow stem cells (BMSC) transplantation in ischemic cardiomyopathy and acute $\mathrm{MI}$ is associated with reducing infarct scar size and improving cardiac functions [4]. These promising results of preclinical studies have led to several clinical trials evaluating the feasibility, safety, and efficacy of combining CABG with BMSC therapy in treating patients with serious IHD. Since the first trial of combined CABG and BMSC transplantation by Stamm et al. [5], several clinical trials that followed have been able to prove both safety and feasibility of this novel approach. However, the efficacy of this therapeutic approach remains controversial as larger, randomized, and multicenter trials are still needed to prove the beneficial effects of this approach [6-8]. 


\section{Discussion}

\section{Methods of BMCs delivery}

BMSCs can be delivered to the injured myocardium via different routes during CABG procedure. The three major techniques used for BMSCs delivery in most studies are

a) Intramyocardial injection.

b) Intracoronary infusion

c) Retrograde coronary sinus delivery.

These approaches are still in the stage of development and implementation. Although the optimum delivery method has yet to be determined, most clinical trials have reported a low frequency of complications regardless of method of BMSCs delivery proving the safety and feasibility of these methods.

Intramyocardial injection: This method of BMSCs delivery is performed by direct multiple injections of cell suspensions into target myocardial areas. The ischemic areas are identified preoperatively using nuclear imaging and echocardiography then visualized directly during the procedure. The prepared BMSC suspension is injected into the border zone of the target area after the graft-coronary anastomosis is completed $[7,9]$. That was the method used by Stamm et al. [5] in the first trial of combined CABG and BMSC therapy. The injections can also be performed at infarcted areas that will not be mechanically revascularized during $\mathrm{CABG}$ due to lack of graftable coronary vessels. This method is considered to be the most reliable and the widest used method of BMSCs delivery during CABG [10]. However, one of its drawbacks is the risk of perforation at the injection site. Also, cell leakage and clumping during injection may cause nonspecific delivery and prevent uniform cell distribution as well [11].

Intracoronary infusion: Infusing the BMSCs via coronary arteries can be performed by injecting the cell suspensions via the saphenous vein graft after distal anastomosis is finished, or injecting it through distal left anterior descending artery before completing the distal anastomosis with the internal thoracic artery. The arteries used for the injection are determined preoperatively by identifying the anatomical feeding vessels of the infarcted area [12]. Unlike intramyocardial injection, this method requires the presence of graftable coronary vessels feeding the target area. Intracoronary infusion has been the most practiced method of BMSCs delivery in catheter-based studies for interventional cardiology [13].

Retrograde coronary sinus delivery: The coronary sinus has been utilized for retrograde delivery of cardioplegic solution in cardiac surgery. A similar technique can be used to deliver the BMSCs via retrograde infusion through the coronary sinus to the coronary veins [14]. Although this method has a theoretical advantage of more homogeneous cell delivery, it is the least investigated method of delivery [15].

\section{Potential mechanisms of action}

In spite of the great expansion of knowledge and experience that has been achieved in the field of regenerative medicine, a major gap still persists in understanding the exact mechanisms of action of cell-based therapies in cardiac regenerative medicine. The oldest presumed mechanism was the direct cell trans differentiation from BMSCs to contracting mature cardiac myocytes replacing the dead ones and restoring the cardiac functions [16]. Another theory was developed later depending on the neovascularization capacity of the transplanted BMSCs. Neovascularization may be beneficial in ischemic situations by increasing blood vessel density and providing a well-developed network of collateral vessels for maintaining adequate blood supply to the ischemic area. However, these benefits are less clear for old infarcted areas with no viable myocardium [17]. Later the paracrine hypothesis was developed referring to the capacity of transplanted BMSCs to release signals and growth factors into extracellular matrix affecting the neighboring cells [18]. Examples of processes associated with the paracrine effect of transplanted BMSCs may include neovascularization, cytokine-induced myocyte growth, stimulation of endogenous myocardial stem cells, preventing overstretch of myocytes and maintain proper electrical behavior of myocardium by extracellular matrix remodeling, inhibition of cardiomyocytes hypertrophic response, and cell fusion between resident myocytes and transplanted BMSCs [19-21].

\section{Autologous versus allogeneic}

Most of the clinical trials for combined CABG and BMSC therapy have investigated autologous cell preparations. Considering the advantage of avoiding immunologic rejection, autologous sources of stem cells have been more attractive for researchers. Nevertheless, autologous stem cell therapy is associated with serious limitations. Especially for patients with serious IHD who are a candidate for CABG, time is a crucial factor that cannot be wasted on tissue harvesting, cell processing, and quality control; which usually are not available at the same facility where the patient will undergo his CABG surgery. In addition, stem cell growth properties may be affected by age as well as other comorbidities that are usually found in those patients $[22,23]$. On the other hand, allogenic sources of stem cells provide "off-the-shelf" and safe solution for those patients being harvested from healthy young donors. Allogeneic stem cell therapy has been proven to be safe and clinical trials combining it with CABG have been started as well $[24,25]$.

\section{Conclusion}

Stem cell therapy for IHD has been receiving a lot of attention over the last decades. With the hope of regenerating dead myocardium and restoring cardiac functions after ischemic related events, researchers all over the world have passionately investigated combined CABG with BMSC therapy. Although both feasibility and safety were proved by several studies, 
controversies about efficacy still remain. Now we are in an exciting phase of regenerative cardiac therapy. Certainly, we still have some challenges in this field including the determining optimal method of delivery, cell type, timing, dosage, cell survival, and retention. In order to address these challenges first, we need more basic science laboratory studies for a better understanding of how this therapeutic approach may work. This will help us improve the efficacy of current approaches and may even give us an opportunity to develop novel approaches. Second, we need to investigate the efficacy of current regenerative therapeutic approaches using larger, placebo-controlled, blinded, randomized, well designed, and multicenter clinical trials. As we move forward in or quest for finding the optimum therapy for IHD, we will definitely get wiser for how we can mend a broken heart.

\section{References}

1. Roger VL, Go AS, Lloyd-Jones DM, Benjamin EJ, Berry JD, et al. (2012) Heart disease and stroke statistics--2012 update: a report from the American Heart Association. Circulation 125(1): e2-e220.

2. Go AS, Mozaffarian D, Roger VL, Benjamin EJ, Berry JD, et al. (2014) Heart disease and stroke statistics--2014 update: a report from the American Heart Association. Circulation 129(3): e28-e292.

3. Levy D, Kenchaiah S, Larson MG, Benjamin EJ, Kupka MJ, et al. (2002) Long-term trends in the incidence of and survival with heart failure. $\mathrm{N}$ Engl J Med 347(18): 1397-1402.

4. Dawn B, Bolli R (2005) Adult bone marrow-derived cells: regenerative potential, plasticity, and tissue commitment. Basic Res Cardiol 100(6): 494-503.

5. Stamm C, Westphal B, Kleine HD, Petzsch M, Kittner C, et al. (2003) Autologous bone-marrow stem-cell transplantation for myocardial regeneration. Lancet 361(9351): 45-46.

6. Mocini D, Staibano M, Mele L, Giannantoni P, Menichella G, et al. (2006) Autologous bone marrow mononuclear cell transplantation in patients undergoing coronary artery bypass grafting. Am Heart J 151(1): 192197.

7. Stamm C, Kleine HD, Choi YH, Dunkelmann S, Lauffs JA, et al. (2007) Intramyocardial delivery of CD133+ bone marrow cells and coronary artery bypass grafting for chronic ischemic heart disease: safety and efficacy studies. J Thorac Cardiovasc Surg 133(3): 717-725.

8. Noiseux N, Mansour S, Weisel R, Stevens LM, Der Sarkissian S, et al (2016) The IMPACT-CABG trial: A multicenter, randomized clinical trial of CD133+ stem cell therapy during coronary artery bypass grafting for ischemic cardiomyopathy. J Thorac Cardiovasc Surg 152(6): 15821588 .

9. Kaminski A, Steinhoff G (2008) Current status of intramyocardial bone marrow stem cell transplantation. Semin Thorac Cardiovasc Surg 20(2): 119-125.

10. Dimmeler S, Zeiher AM, Schneider MD (2005) Unchain my heart: the scientific foundations of cardiac repair. J Clin Invest 115(3): 572-583.
11. Kocher AA, Schlechta B, Gasparovicova A, Wolner E, Bonaros N, et al. (2007) Stem cells and cardiac regeneration. Transpl Int 20(9): 731746.

12. Hu S, Liu S, Zheng Z, Yuan X, Li L, et al. (2011) Isolated coronary artery bypass graft combined with bone marrow mononuclear cells delivered through a graft vessel for patients with previous myocardial infarction and chronic heart failure: a single-center, randomized, double-blind, placebo-controlled clinical trial. J Am Coll Cardiol 57(24): 2409-2415.

13. Dib N, Menasche P, Bartunek JJ, Zeiher AM, Terzic A, et al. (2010) Recommendations for successful training on methods of delivery of biologics for cardiac regeneration: a report of the International Society for Cardiovascular Translational Research. JACC Cardiovasc Interv 3(3): 265-275.

14. Giordano FJ (2003) Retrograde coronary perfusion: a superior route to deliver therapeutics to the heart?* J Am Coll Cardiol 42(6): 1129-1131.

15. Raake P, von Degenfeld G, Hinkel R, Vachenauer R, Sandner T, et al. (2004) Myocardial gene transfer by selective pressure-regulated retroinfusion of coronary veins: comparison with surgical and percutaneous intramyocardial gene delivery. J Am Coll Cardiol 44(5): 1124-1129.

16. Orlic D, Kajstura J, Chimenti S, Jakoniuk I, Anderson SM, et al. (2001) Bone marrow cells regenerate infarcted myocardium. Nature 410(6829): 701-705.

17. Kawamoto A, Iwasaki H, Kusano K, Murayama T, Oyamada A, et al (2006) CD34-positive cells exhibit increased potency and safety for therapeutic neovascularization after myocardial infarction compared with total mononuclear cells. Circulation 114(20): 2163-2169.

18. Mirotsou M, Jayawardena TM, Schmeckpeper J, Gnecchi M, Dzau VJ (2011) Paracrine mechanisms of stem cell reparative and regenerative actions in the heart. J Mol Cell Cardiol 50(2): 280-289.

19. Anversa P, Leri A, Kajstura J (2006) Cardiac regeneration. J Am Coll Cardiol 47(9): 1769-1776.

20. Alvarez-Dolado M, Pardal R, Garcia-Verdugo JM, Lee HO, Pfeffer K, et al (2003) Fusion of bone-marrow-derived cells with Purkinje neurons, cardiomyocytes and hepatocytes. Nature 425(6961): 968-973.

21. Tse HF, Siu CW, Zhu SG, Songyan L, Zhang QY, et al. (2007) Paracrine effects of direct intramyocardial implantation of bone marrow derived cells to enhance neovascularization in chronic ischaemic myocardium. Eur J Heart Fail 9(8): 747-753.

22. Dimmeler S, Leri A (2008) Aging and disease as modifiers of efficacy of cell therapy. Circ Res 102(11): 1319-1330.

23. Malliaras K, Kreke M, Marban E (2011) The stuttering progress of cell therapy for heart disease. Clin Pharmacol Ther 90(4): 532-541.

24. Hare JM, Fishman JE, Gerstenblith G, DiFede Velazquez DL, Zambrano JP, et al. (2012) Comparison of allogeneic vs autologous bone marrowderived mesenchymal stem cells delivered by transendocardial injection in patients with ischemic cardiomyopathy: the poseidon randomized trial. JAMA 308(22): 2369-2379.

25. Anastasiadis K, Antonitsis P, Westaby S, Reginald A, Sultan S, et al. (2016) Implantation of a Novel Allogeneic Mesenchymal Precursor Cell Type in Patients with Ischemic Cardiomyopathy Undergoing Coronary Artery Bypass Grafting: an Open Label Phase IIa Trial. J Cardiovasc Transl Res 9(3): 202-213. 
This work is licensed under Creative Commons Attribution 4.0 License

DOI: $10.19080 /$ JOCCT.2017.04.555630

\section{Your next submission with Juniper Publishers} will reach you the below assets

- Quality Editorial service

- Swift Peer Review

- Reprints availability

- E-prints Service

- Manuscript Podcast for convenient understanding

- Global attainment for your research

- Manuscript accessibility in different formats

( Pdf, E-pub, Full Text, Audio)

- Unceasing customer service

Track the below URL for one-step submission https://juniperpublishers.com/online-submission.php 